\title{
Analysis of Future Teachers' Perceptions on the Evaluation of Learning: A Case Study of Chile
}

\author{
José Hernández Sepúlveda \\ Universidad Católica del Maule, Talca, Chile \\ https:// orcid.org/0000-0002-6168-4368 \\ Rodrigo Panes Chavarría \\ Universidad del Bio Bio, Chillan, Chile \\ https://orcid.org/0000-0002-2400-6701 \\ Karla Rosalía Morales Mendoza \\ Universidad Católica del Maule, Talca, Chile \\ https://orcid.org/0000-0001-5807-3876
}

\begin{abstract}
Practising teachers and future Chilean teachers show weaknesses in developing learning evaluation processes efficiently. The polysemic concept of evaluation in Initial Teacher Training (FID, Spanish acronym for Initial Teacher Training) is one of the main difficulties for the students of pedagogy as well as their limited possibilities to implement practical evaluation processes. In this context, the present work analyses the perceptions of 189 students from different pedagogy careers (Chile) on the evaluation of learning. The current study is descriptive research with a quantitative approach in which a questionnaire was designed and used as research instrument to address the conceptual, functional and experiential dimensions of the evaluation. The results indicate that the perceptions of the evaluation of the students are up to date and according to specialised literature. Likewise, the results show that the training experiences are based on traditional perceptions, such as the control and value given to the evaluation instrument. However, there were statistically significant differences between the groups which were measured by the KruskalWallis $\mathrm{H}$ test. The projection of the study leads us to suggest that for the training of future teachers, instances of reflective action in the evaluation should be considered, based on professional practices. The recognition of educational communities and their environments is necessary to give rise to an evaluative praxis that relates the perceptions of students to the practical implementation of the evaluation processes to have a favourable impact on the training of future teachers.
\end{abstract}

Keywords: evaluation; initial teacher training; perception; teachers 


\section{Introduction}

The evaluation of learning over time has increased in complexity owing to the great variety of conceptions, functions, and purposes that have been incorporated into this process. Currently, it is not easy to conceptualise the term because the idea of evaluation causes some confusion in educational institutions. The term might also mean to measure a student's performance, to grade performance, to select the best, to improve teaching, and to build learning, among others (Santos Guerra, 2003; Stobar, 2010). Therefore, it can be said that the concept of learning evaluation is a polysemic term (Castillo \& Cabrerizo, 2010) since in the educational field, although different notions can be valued, in all of them there are common and valid elements to construct a definition (Santos Guerra, 2003; Escudero, 2003). For the present study, it is important to contextualise and illustrate the evolution of learning evaluation. For this purpose, a theoretical analysis of the moments and movements contributing to the development of the evaluation over time is carried out. This describes the results of teachers and future teachers quantitatively corresponding to the Teaching Portfolio and National Diagnostic Assessment Initiates Test as applied by the Centre for Improvement, Experimentation and Pedagogical Research (henceforth, CPEIP).

\section{State of the Art: Evolution of the Evaluation}

At the end of the 19th century and the beginning of the 20th century, the evaluation of learning focused fundamentally on standardised tests to measure all kinds of school skills. This was done to determine the position that future teachers obtained within the group norm, generalising the results with a common pattern, identifying the differences and/or inequalities between groups, which in practice only focused on measurement (Fernández, 1981; Escudero 2003).

In the middle of the 20th century, Tyler (1950) made a significant advance in the development of evaluation. From the behavioural approach, he overcame mere psychological evaluation by relying on a more methodical and organised perspective of the evaluation process. His approach was focused on the use of clearly defined objectives through the construction and use of appropriate instruments to obtain information. This was to determine to what extent learning was achieved in the teaching programmes and curricula, generating an important change in the conception of evaluation that existed at that time (Escudero, 2003; Castillo Cabrerizo, 2010).

During the 1960s, the evaluation of learning evolved again since it not only had to focus on the learning objectives that students achieved, but it was also necessary to consider collecting information on a comprehensive educational programme (Cronbach, 1963). This perspective of evaluation is consistent with the incorporation of the interpretive paradigm in which evaluative practice becomes a process that enables establishing the merit or value of what is evaluated. Moreover, at this time the concepts of summative and formative assessment were incorporated (Scriven, 1967). Summative assessment is understood as a reductionism of the educational process, given that the 
emphasis is on measuring or grading learning, while formative assessment seeks the student's self-regulation as it favours the learner's processes of reflection on his or her own training process.

Starting in the 1970s, there was a proliferation of evaluation models characterised by conceptual, methodological and paradigmatic plurality. Authors such as Guba and Lincoln (1982) indicated that there were more than 40 evaluation models which pointed to two areas. The first considered the students and the methods, while the second focused on the change that occurred with the students based on the educational action according to the formulation of previously designed learning objectives. At the same time, well-known taxonomies, developed mainly by authors such as Bloom (1969), Gagné (1971) and Mager (1973), were incorporated into the evaluation.

During the 1970s there were two periods with clear conceptual and methodological differences. One period followed the line of Tyler, which was based on the achievement of predefined objectives and was supported by the positivist paradigm, while the other alternative models were based on the constructivist interpretive paradigm. Among the best known are the responsible evaluation of Stake in 1975, the democratic evaluation of Macdonald in 1976, the illuminative evaluation of Parlett and Hamilton in 1977 and the evaluation as an art critic of Eisner in 1985, among others (Alcaraz, 2015; Carbajosa, 2011; Escudero, 2003).

More recently, at the end of the 20th century and the beginning of the 21st century, the evaluation of learning again faces a process of evolution, since after the Bologna treaty (1999), the curriculum by objectives used for years in professional training was replaced by a curriculum based on competency. This new approach is not exempt from criticism because for some authors, the idea of a curriculum by competencies corresponds to normative instruments with which the convergence of school systems is sought (Sacristán et al., 2008). Researchers who oppose the new training model consider that it takes competencies as a reference for the structure of a globalised curriculum in which these will be used to choose procedures and proposals for evaluation.

The change in the training approach presented a great challenge in higher education, both in the design and in the development and evaluation of the professional training processes (Tejada \& Ruiz, 2016). In the field of evaluation, authors such as Dochy, Segers and Dierick (2002) argued that the greatest difficulty for the universities is to move from a culture of examination to a culture of evaluation, where evaluative practices are developed with a formative idea. The second one aimed to improve the learning of students and involve them in the evaluation processes (Cano, 2008; Ruay, 2019; Stobart, 2010; Tejada \& Ruiz, 2016). Bonsón and Benito (2005) considered that it is necessary to advance from the evaluation of learning to the evaluation for learning, or as the authors Carless, Joughin and Mok (2006) and Bound and Falchikov (2007) put it, to a learning-oriented assessment. 
In this new evaluative framework, the competencies that the students of pedagogy careers managed to acquire in the dimension of educational activities were considered. This is because the evaluation of learning is one of the fundamental activities that are developed in educational organisations; therefore, it is considered a basic teaching competence (Perrenoud, 2004; Zabalza, 2003). Additionally, the specialised literature shows that evaluative practices are indisputably instances of improvement of learning as well as of teaching quality (Black \& William, 1998; Ruay, 2019; Tejada \& Ruiz, 2016).

\section{Competency Assessment as an Improvement Alternative}

The incorporation of the competency model in teacher training involves a great change in teaching since there is a transition from teaching to learning, where the evaluation processes, the design, and development of the professional teaching construction are taken into consideration. This is because it requires an adequate alignment between the curricular pedagogical designs, the methodology, and the evaluation of teacher training without losing sight of the graduation profiles and the standards associated with the individualities of each training process (Biggs, 2010; Moreno Oliver, 2014; Yáñiz \& Villardón, 2006, as cited in Tejada \& Ruiz, 2016).

Consequently, evaluation from the competency approach acquires meaning, significance and relevance according to the conditions in which it is evidenced (Tejada \& Ruiz, 2016). That is why the actions that are implemented must approach real problems, where contextual situations are a source of specification of competencies with the student as the protagonist (Salazar-Gómez \& Tobón, 2018).

In Initial Teacher Training (hereafter, FID) it is not always possible to maintain the connection with the professional scenario; therefore future professionals must make/adopt? approaches based on the simulation of problems or situated reality (Littlewood, 2011; McGaghie et al., 2010; Ros \& Conesa, 2013). This is to be done so that the actions are carried out from an authentic evaluation in which feedback to the student prevails, as well as an assessment of the performance achieved (Tejada \& Ruiz, 2016). The training process is complex and multidimensional; therefore it needs to be evaluated in different ways (Fernández, 2010), putting aside the old culture of evaluation that focused on written and oral tests based on the management of rote knowledge and the generalisation of the results.

This new perspective of evaluation involves various evaluative strategies and instruments so that the necessary background information can be collected about the acquisition of generic and specific competencies to assess the results that students in training are expected to achieve in concordance with the planning and programming of learning for their professional teaching development. In other words, evaluation by competencies is a complex process that must be oriented to the student's action, based on real or simulated work situations that favour tasks of authentic evaluation (Del Pozo, 2013; AshfordRowe, Herrington \& Brown, 2014). The evaluation by competencies also focuses 
on the fact that the learners manage to integrate the repertoire of knowledge, abilities, and aptitudes to solve the problems that demand acting professionally, favouring the learning process and not only measuring the meaningless results.

On the other hand, assessment by competencies has different perspectives, including assessment of learning, for learning, as learning and from learning. Some authors such as Brown and Pickford (2013), Ion, Silva and Cano (2008), Nicol, Thomson and Breslin (2014) and Villardón (2006), cited in Tejada and Ruiz (2016) consider that the meaning is given to the classical formative and summative evaluation from a complementary approach in the way that the first (formative) corresponds to the development of competencies. Therefore, it emphasises learning activities and their permanent improvement, continuous feedback, reflection on the process, and self-evaluation. However, in the second (summative) evaluation, competency is evaluated by connecting it with performance, levels of achievement, and evidence (Tejada \& Ruiz, 2016).

From the perspective of the development of evaluation by competencies, the educational system in general and the FID in particular are obliged to innovate and reformulate their pedagogical and evaluative practices. Since the competencies arise as a response to the need to articulate the knowledge that future teachers must possess to face the workplace, this undoubtedly leaves evaluation at a didactic crossroads. This is because the implementation is not immune to the tensions and challenges that new teaching practices seek to address (Cano, 2008).

For authors such as Scriven (2007), Hall and Burke (2008) and Kaftan, Buck and Haack (2006), evaluation has its essence in the formative as an integral learning process as long as it establishes a formative design that enhances the educational process and the construction of new knowledge. Therefore, the evaluation training that students receive in their initial training must also contribute to the development of self-learning and self-regulation so that students are aware of their practices and learning (Ríos \& Herrera, 2017).

The evaluation by competencies should be oriented to the development of learning for life, relating knowledge, knowing how to do and knowing how to be, since at this point the different learning experiences intersect from a transversal perspective, highlighting the educational daily life as the main setting (Jaimes \& Callejas, 2009). Likewise, Tobón (2004) stated, "the evaluation of competencies must integrate the qualitative with the quantitative, because with words it cannot be measured, and with numbers, it cannot be understood or explained", which forces us to think that both contribute to the improvement of teaching and learning processes. Bolívar (2008) cited in Cano (2008):

"The best way to evaluate competencies is to put the subject before a complex task, to see how he/she manages to understand and solve it by mobilizing knowledge. The evaluation instruments used cannot be limited to tests to see the degree of mastery of content or objectives, but rather propose complex situations, belonging to the family of situations defined by the competencies, which will also require a complex 
production by the student to solve the situation, since he/she needs knowledge, attitudes, metacognitive thinking." (p. 184)

In this way, it can be clarified that the evaluation by competencies is a global construct that must be designed and structured to enhance the educational process, establishing criteria that allow appreciating and demonstrating the learning and performance obtained by students in training. It corresponds to concern about the effectiveness of the activities designed in the study programmes to ensure the fulfilment and achievement of the students' learning regarding each graduation profile (Cano, 2008).

Finally, the evaluation by competencies must be understood from the training point of view to favour the permanent improvement of the teaching and learning processes. Likewise, this should promote self-regulation and selflearning of students through responsibility, criticism and self-criticism of their own educational process (Stobart, 2010; Tejada \& Ruíz, 2016). Equally, it is necessary to consider that the constant improvement of learning is the ultimate goal. Therefore, students are the main actors in evaluative practices and actions that when analysed with teachers in dialogic spaces, allow students to become aware of the level reached.

\section{Teacher Evaluation System and Future Teachers in the Chilean National Context}

The Ministry of Education, through the CPEIP, developed teacher evaluation with the objective of strengthening the teaching profession and contributing to improving the quality of education in Chile. The results published in 2018 with the item titled "Evaluation and Correction Guideline Used" indicate that $34 \%$ of all the teachers evaluated at the national level were in the category of 'Competent and Outstanding'. The remaining $64 \%$ were in the category of 'Unsatisfactory and Basic'. Later in the item, 'Relationship between evaluation and objectives' indicates that $44 \%$ of the teachers were competent and outstanding, and 56\% were unsatisfactory and basic. Finally, in the item 'Analysis and use of evaluation results' only $17 \%$ of teachers were competent and outstanding, and 83\% were unsatisfactory and basic (Ministerio de Educación, 2019a).

On the other hand, the results also highlighted that the best-evaluated teachers, that is, those who achieve competent and outstanding performances, show low results in the tasks that correspond to the evaluation of learning and reflection from the results (Table 1 ). 
Table 1: Portfolio performance in competent and outstanding teachers

\begin{tabular}{|c|c|c|}
\hline Evaluated aspect & Description of the competition & $\begin{array}{l}\text { Total } \% \\
\text { proficient } \\
\text { outstanding } \\
\text { teachers }\end{array}$ \\
\hline $\begin{array}{l}\text { Evaluation and } \\
\text { correction } \\
\text { guideline }\end{array}$ & $\begin{array}{l}\text { Proposes instructions, questions or tasks in } \\
\text { the evaluation that are clear, and in its } \\
\text { correction guideline, it correctly identifies } \\
\text { the expected performance }\end{array}$ & $41.8 \%$ \\
\hline $\begin{array}{l}\text { Relationship } \\
\text { between evaluation } \\
\text { and objectives }\end{array}$ & $\begin{array}{l}\text { Performs assessment activities that address } \\
\text { and are consistent with all of the learning } \\
\text { objectives you set out to measure }\end{array}$ & $51.1 \%$ \\
\hline $\begin{array}{l}\text { Accountability for } \\
\text { results }\end{array}$ & $\begin{array}{l}\text { Manages to recognise the influence of the } \\
\text { pedagogical decisions, both in the learning } \\
\text { achieved and not achieved }\end{array}$ & $45.0 \%$ \\
\hline $\begin{array}{l}\text { Analysis based on } \\
\text { the characteristics } \\
\text { of your students }\end{array}$ & $\begin{array}{l}\text { Demonstrates knowing the characteristics of } \\
\text { the students and incorporates them when } \\
\text { planning or conducting his/her classes, } \\
\text { seeking to promote learning }\end{array}$ & $47.2 \%$ \\
\hline $\begin{array}{l}\text { Formative use of } \\
\text { learning } \\
\text { difficulties }\end{array}$ & $\begin{array}{l}\text { Identifies the difficulties that their students } \\
\text { present during the learning process. Reflects } \\
\text { on them and the way to approach them } \\
\text { formatively }\end{array}$ & $60.9 \%$ \\
\hline $\begin{array}{l}\text { Feedback to your } \\
\text { students }\end{array}$ & $\begin{array}{l}\text { Provides feedback to the students, allowing } \\
\text { them to learn from their own performance } \\
\text { since it encourages them to complement } \\
\text { their answers, analyse the steps they } \\
\text { followed to arrive at a result or identify the } \\
\text { reason for their successes or errors }\end{array}$ & $26.7 \%$ \\
\hline
\end{tabular}

Source: Mineduc (Ministry of Education, Chile, 2019a)

On the other hand, in the case of future teachers, the results of the National Diagnostic Evaluation of Initial Teacher Training (END - FID) of 2018 (CPEIP, 2018) showed that in the standard called 'Knowing how to apply evaluation methods to observe the progress of students and knowing how to use the results to provide feedback on learning and pedagogical practice', the future teachers of pedagogy careers who participated in the study did not have the necessary knowledge to achieve optimal performance according to the applied instrument (Ministerio de Educación, 2019b). (Table 2).

Table 2: National diagnostic evaluation in initial teacher training

\begin{tabular}{|l|l|l|l|l|}
\hline Pedagogy career & Performance standard & $\begin{array}{l}\% \\
\text { correct }\end{array}$ & $\begin{array}{l}\% \\
\text { Min }\end{array}$ & \% Max \\
\hline $\begin{array}{l}\text { Pedagogy in } \\
\text { English }\end{array}$ & $\begin{array}{l}3.0 \text { Knows the curriculum of } \\
\text { Secondary Education and uses its } \\
\text { various curricular instruments to } \\
\text { analyze and formulate pedagogical } \\
\text { and evaluative proposals }\end{array}$ & $50.4 \%$ & $0.0 \%$ & $80.0 \%$ \\
\hline $\begin{array}{l}\text { Pedagogy in } \\
\text { English }\end{array}$ & $\begin{array}{l}6.0 \text { Knows how to apply evaluation } \\
\text { methods to observe the progress of } \\
\text { students and knows how to use the }\end{array}$ & $58.9 \%$ & $33.3 \%$ & $69.1 \%$ \\
\hline
\end{tabular}




\begin{tabular}{|c|c|c|c|c|}
\hline & $\begin{array}{l}\text { results to provide feedback on } \\
\text { learning and pedagogical practice }\end{array}$ & & & \\
\hline $\begin{array}{l}\text { Pedagogy in } \\
\text { Spanish } \\
\text { Language and } \\
\text { Communication }\end{array}$ & $\begin{array}{l}3.0 \text { Knows the curriculum of } \\
\text { Secondary Education and uses its } \\
\text { various curricular instruments to } \\
\text { analyse and formulate pedagogical } \\
\text { and evaluative proposals }\end{array}$ & $58.7 \%$ & $35 \%$ & $69.1 \%$ \\
\hline $\begin{array}{l}\text { Pedagogy in } \\
\text { Spanish } \\
\text { Language and } \\
\text { Communication }\end{array}$ & $\begin{array}{l}6.0 \text { Knows how to apply evaluation } \\
\text { methods to observe the progress of } \\
\text { students and knows how to use the } \\
\text { results to provide feedback on } \\
\text { learning and pedagogical practice }\end{array}$ & $61.7 \%$ & $40.7 \%$ & $73.1 \%$ \\
\hline $\begin{array}{l}\text { Pedagogy in } \\
\text { Physical } \\
\text { Education }\end{array}$ & $\begin{array}{l}3.0 \text { Knows the curriculum of } \\
\text { Secondary Education and uses its } \\
\text { various curricular instruments to } \\
\text { analyse and formulate pedagogical } \\
\text { and evaluative proposals }\end{array}$ & $42.3 \%$ & $30.0 \%$ & $53.9 \%$ \\
\hline $\begin{array}{l}\text { Pedagogy in } \\
\text { Physical } \\
\text { Education }\end{array}$ & $\begin{array}{l}6.0 \text { Knows how to apply evaluation } \\
\text { methods to observe the progress of } \\
\text { students and knows how to use the } \\
\text { results to provide feedback on } \\
\text { learning and pedagogical practice }\end{array}$ & $50.1 \%$ & $28.6 \%$ & $62.7 \%$ \\
\hline $\begin{array}{l}\text { Pedagogy in } \\
\text { Religion and } \\
\text { Philosophy }\end{array}$ & $\begin{array}{l}3.0 \text { Knows the curriculum of } \\
\text { Secondary Education and uses its } \\
\text { various curricular instruments to } \\
\text { analyse and formulate pedagogical } \\
\text { and evaluative proposals }\end{array}$ & $58.7 \%$ & $30.0 \%$ & $76.0 \%$ \\
\hline $\begin{array}{l}\text { Pedagogy in } \\
\text { Religion and } \\
\text { Philosophy }\end{array}$ & $\begin{array}{l}6.0 \text { Knows how to apply evaluation } \\
\text { methods to observe the progress of } \\
\text { students and knows how to use the } \\
\text { results to provide feedback on } \\
\text { learning and pedagogical practice }\end{array}$ & $55.6 \%$ & $44.9 \%$ & $66.7 \%$ \\
\hline $\begin{array}{l}\text { Pedagogy in } \\
\text { Differential } \\
\text { Education }\end{array}$ & $\begin{array}{l}3.0 \text { Knows the curriculum of } \\
\text { Secondary Education and uses its } \\
\text { various curricular instruments to } \\
\text { analyse and formulate pedagogical } \\
\text { and evaluative proposals }\end{array}$ & $46.6 \%$ & $33.3 \%$ & $61.5 \%$ \\
\hline $\begin{array}{l}\text { Pedagogy in } \\
\text { Differential } \\
\text { Education }\end{array}$ & $\begin{array}{l}6.0 \text { Knows how to apply evaluation } \\
\text { methods to observe the progress of } \\
\text { students and knows how to use the } \\
\text { results to provide feedback on } \\
\text { learning and pedagogical practice }\end{array}$ & $46.0 \%$ & $33.3 \%$ & $56.9 \%$ \\
\hline
\end{tabular}

Source: National Diagnostic Evaluation in Initial Teacher Training (Ministerio de Educación, 2019b).

The results of the national diagnostic evaluation in the FID showed that the students of pedagogy careers obtain low performances in the standards that are associated with the evaluation of learning, a situation that is repeated in the professional field. The teachers of the Chilean educational system also obtained low results in the evaluation task framed in the portfolio of the Teacher Evaluation (CPEIP, 2018; Teacher Performance Evaluation System, 2019). There is a need to analyse the perceptions of final-year students of the pedagogy 
careers of the Catholic University of Maule about the evaluation of learning and how their evaluative experiences have been owing to many reasons. Some of these are the following:

- The profound transformations that the concept of evaluation and its functions have undergone throughout history;

- The low results obtained by pedagogy students and teachers of the educational system in the field of learning evaluation;

- The incorporation of a new training model for the evaluation programmes of university pedagogy careers; and

- The scarce presence of scientific studies on the ideas that future teachers have regarding the evaluation of learning in Chile.

\section{Materials and Methods}

According to the objectives set, the approach that fits the study is quantitative (Hernández, Fernández \& Baptista, 2010). The chosen design corresponded to the non-experimental, descriptive exploratory survey type (Tejedor, 2000; Colás, 1994). Such decisions make it possible to inquire about a little-studied topic and provide an important source of information to learn about perceptions of and possible differences between groups of students.

\subsection{Research Instruments}

To assess the perceptions of the students, a Likert-type questionnaire with two differentiated parts was designed. In the first one, information was requested on demographic variables (gender, age, degree, grade). In the second part, and to collect information related to the objectives of this study, 31 items were presented, distributed in three dimensions (Table 3), where the respondents marked their degree of agreement from 1 (totally disagree) to 5 (totally agree).

Table 3: Psychometric characteristics of the instrument

\begin{tabular}{|l|l|l|}
\hline $\begin{array}{l}\text { No. of } \\
\text { dimensions }\end{array}$ & Name of the dimension & $\begin{array}{l}\text { No. of descriptors/ } \\
\text { dimension }\end{array}$ \\
\hline I dimension & Perceptions about learning assessment & 10 (ten) \\
\hline II dimension & $\begin{array}{l}\text { Perception of the role of evaluation in } \\
\text { teaching and learning processes }\end{array}$ & 14 (fourteen) \\
\hline III dimension & $\begin{array}{l}\text { Perception of evaluation during the } \\
\text { training process and professional practices }\end{array}$ & 7 (seven) \\
\hline
\end{tabular}

Source: Own elaboration

For the elaboration of the instrument, a review of specialised literature was carried out, giving significance to the instruments' items. Subsequently, it was evaluated by five experts from the Universidad Católica del Maule based on the sufficiency, clarity, and relevance of each of the items and the contributions of which indicate a C.V.I. (Content validity index) corresponding to 0.9. After evaluation by experts, the survey was subjected to a first analysis to estimate its reliability. It yielded a Cronbach's alpha coefficient of .760, indicating good internal consistency. 


\subsection{Participants}

For the present study, using a non-probability sampling, 189 fourth-year students of the Pedagogy career courses from the Catholic University of Maule were chosen as the participants of the study (Cardona, 2002). These are distributed according to the following five career courses: Pedagogy in English (24), Pedagogy in Spanish Language and Communication (18), Pedagogy in Physical Education (65), Pedagogy in Religion and Philosophy (46), and Pedagogy in Differential Education (36).

The ages of the participants vary between 22 and 24 years. With regard to gender, women $(n=123 ; 65.1 \%)$ predominate over men $(n=66 ; 34.9 \%)$. All of the participants have taken the learning assessment course; moreover, each one of them has been assessed throughout their training process from the first levels of teaching. It should be noted that all future teachers would continue to be evaluated once they pass their teaching careers by the teacher professional development system governed by Law No. 20.903 of the Ministry of Education of Chile (Teaching Career Act, Ministry of Education, 2016).

\subsection{Procedures and Data Analysis}

A pollster applied the questionnaire during the regular sessions of the courses. On each occasion, the participants were informed about the objectives of the study and were asked to sign an informed consent to safeguard the ethical principles of the research.

The data analysis considered descriptive and inferential techniques. Using SPSS software, measures of central tendency (mean) and dispersion measures (standard deviation) were calculated, and percentages were obtained for each variable of the study. Moreover, the Kruskal-Wallis $\mathrm{H}$ test was used to search for statistically significant differences between the groups.

\section{Results}

Following the order of the objectives, the results that account for the perceptions of the students for each dimension of the study are presented in Table 4 . Subsequently, the results obtained by comparing the perceptions raised in the instrument are shown according to the career courses taken by the students.

Table 4: Perceptions about learning evaluation

\begin{tabular}{|l|c|c|c|c|c|c|c|}
\hline Descriptors & $\mathbf{M}$ & $\mathbf{S D}$ & $\begin{array}{c}\text { TD } \\
\%\end{array}$ & $\begin{array}{c}\text { PD } \\
\%\end{array}$ & $\begin{array}{c}\text { NA/ND } \\
\%\end{array}$ & $\begin{array}{c}\text { PA } \\
\%\end{array}$ & $\begin{array}{c}\text { TA } \\
\%\end{array}$ \\
\hline Evaluating is the same as grading. & 1.48 & .93 & $\underline{73}$ & 14.3 & 6.9 & 3.9 & 2.1 \\
\hline $\begin{array}{l}\text { When one talks about evaluating, the } \\
\text { focus is on the evaluation instrument. }\end{array}$ & 3.26 & 1.3 & 13.2 & 17.5 & 17.5 & $\underline{33.9}$ & $\underline{18}$ \\
\hline $\begin{array}{l}\text { The most effective evaluation } \\
\text { corresponds to the written evaluation } \\
\text { since it better predicts a student's } \\
\text { learning achievement. }\end{array}$ & 2.13 & 1.1 & $\underline{36}$ & $\underline{31.7}$ & 19 & 10.1 & 3.2 \\
\hline $\begin{array}{l}\text { The evaluation of learning is } \\
\text { considered a communication } \\
\text { instrument that facilitates the } \\
\text { construction of knowledge within the } \\
\text { classroom. }\end{array}$ & 3.51 & 1.1 & 3.7 & 15.3 & 23.8 & $\underline{40.2}$ & 16.9 \\
\hline
\end{tabular}




\begin{tabular}{|l|c|c|c|c|c|c|c|}
\hline $\begin{array}{l}\text { The psychometric evaluation has the } \\
\text { same function as the formative } \\
\text { pedagogical evaluation. }\end{array}$ & 2.47 & 1.0 & $\underline{24.9}$ & 15.3 & $\underline{49.7}$ & 8.5 & 1.6 \\
\hline $\begin{array}{l}\text { Evaluation in education is a linear } \\
\text { process. }\end{array}$ & 3.10 & 1.3 & 16.9 & 11.1 & $\underline{29.6}$ & 29.6 & 12.7 \\
\hline $\begin{array}{l}\text { The evaluation of learning must be } \\
\text { fully integrated into the teaching- } \\
\text { learning process that is being carried } \\
\text { out. }\end{array}$ & 4.26 & .97 & 1.6 & 6.9 & 6.9 & $\underline{32.8}$ & $\underline{51.9}$ \\
\hline $\begin{array}{l}\text { The competency-based assessment } \\
\text { has the same emphasis as pedagogical } \\
\text { assessment. }\end{array}$ & 2.62 & 1.0 & 19 & 21.7 & $\underline{38.1}$ & 20.1 & 1.1 \\
\hline Evaluating is the same as measuring. & 2.60 & 1.3 & $\underline{26.5}$ & $\underline{22.8}$ & $\underline{24.3}$ & $\underline{16.9}$ & 9.5 \\
\hline $\begin{array}{l}\text { Assessing is focusing on student } \\
\text { grades. }\end{array}$ & 2.28 & 1.3 & $\underline{36}$ & $\underline{25.9}$ & 19.6 & 11.1 & 7.4 \\
\hline
\end{tabular}

$\mathrm{M}=$ Mean, $\mathrm{SD}=$ Standard Deviation, $\mathrm{TD}=$ Totally Disagree, $\mathrm{PD}=$ Partially Disagree, NA $/$ ND $=$ Neither Agree $/$ Neither Disagree, PA = Partially Agree, $\mathrm{TA}=$ Totally Agree

In general terms, the items of the dimension perceptions of the students about the evaluation of learning show us that they are capable of responding to questions related to the evaluation. Only $25.3 \%$ on average of the respondents are not capable of the items consulted.

At a particular level, the values show us that $87.3 \%$ of the sample totally disagreed or partially disagreed before the consultation whether evaluating is the same as grading $(\mathrm{M}=1.48, \mathrm{SD}=0.93)$. In the same way, a rating below the mean was noted when they are asked whether evaluating is the same as measuring $(\mathrm{M}=$ $2.6, \mathrm{SD}=1.3)$, or whether assessing is focusing on students' grades $(\mathrm{M}=2.28, \mathrm{SD}=$ $1.3)$.

These responses correspond to the items' moderately low ratings, the psychometric evaluation has the same function as the formative pedagogy evaluation (M $=2.47, \mathrm{SD}=1.0)$ and competency-based assessment has the same emphasis as pedagogical assessment $(\mathrm{M}=2.62, \mathrm{SD}=1.0)$. A total of $67.7 \%$ of the respondents were declared to be totally or partially in disagreement while referring to the effectiveness of the written evaluation $(\mathrm{M}=2.13)$ to predict student achievement.

On the other hand, over $50 \%$ of the participants $(\mathrm{PA}=33.9 \%$, TA $=18 \%$ ) positively valued the evaluation focused on the instrument $(\mathrm{M}=3.26, \mathrm{SD}=1.3)$. Correspondingly, the group of pedagogy students recognised the evaluation as a process integrated into teaching and learning $(\mathrm{M}=4.26 ; \mathrm{PA}=32.8 \%, \mathrm{TA}=51.9 \%)$ and as a constitutive part of the communication instruments that facilitate the construction of knowledge within the classroom $(\mathrm{M}=3.51, \mathrm{SD}=1.1)$. The above results are shown in Table 5. 
Table 5: Perception of the role of evaluation in teaching and learning processes

\begin{tabular}{|c|c|c|c|c|c|c|c|}
\hline Descriptors & $\mathbf{M}$ & SD & $\begin{array}{c}\text { TD } \\
\%\end{array}$ & $\begin{array}{c}\mathrm{PD} \\
\%\end{array}$ & $\begin{array}{l}\text { NA/ND } \\
\quad \%\end{array}$ & $\begin{array}{c}\text { PA } \\
\%\end{array}$ & $\begin{array}{c}\text { TA } \\
\%\end{array}$ \\
\hline $\begin{array}{l}\text { Evaluation in education is an } \\
\text { important tool to measure the } \\
\text { achievement of student learning. }\end{array}$ & $\underline{3.96}$ & 1.7 & 3.2 & 9.0 & 13.2 & 37.6 & 37.0 \\
\hline $\begin{array}{l}\text { Learning assessment is essential to } \\
\text { grade students. }\end{array}$ & $\underline{3.46}$ & 1.1 & 6.3 & 13.2 & 24.3 & 40.2 & 15.9 \\
\hline $\begin{array}{l}\text { Learning assessment allows the } \\
\text { teacher to compare their students } \\
\text { based on the results they obtain. }\end{array}$ & $\underline{3.59}$ & 1.1 & 6.3 & 9.5 & 21.7 & 43.9 & 18.5 \\
\hline $\begin{array}{l}\text { It is important to grade students to } \\
\text { see whether they should be promoted } \\
\text { or failed. }\end{array}$ & 3.12 & 1.2 & 10.6 & 22.8 & 20.1 & 37.6 & 9.0 \\
\hline $\begin{array}{l}\text { The evaluation is an instrument that } \\
\text { allows to know the students. }\end{array}$ & 3.48 & 1.4 & 12.7 & 13.8 & 14.8 & 30.7 & 28.0 \\
\hline $\begin{array}{l}\begin{array}{l}\text { Evaluation is a } \begin{array}{l}\text { mechanism that } \\
\text { regulates } \\
\text { process. }\end{array} \\
\text { the }\end{array} \text { teaching-learning } \\
\end{array}$ & 3.78 & 1.0 & 2.6 & 7.9 & 21.2 & 45.5 & 22.8 \\
\hline $\begin{array}{l}\text { Student assessment is a useful } \\
\text { practice for the teacher. }\end{array}$ & 3.96 & 0.9 & 2.1 & 5.3 & 15.9 & 47.6 & 29.1 \\
\hline $\begin{array}{l}\text { Once an assessment instrument has } \\
\text { been applied, it is necessary to } \\
\text { analyse the results with the students. }\end{array}$ & 4.54 & 0.8 & 2.1 & 1.6 & 3.7 & 25.4 & 67.2 \\
\hline $\begin{array}{l}\text { Learning assessment allows students } \\
\text { to self-regulate their educational } \\
\text { processes. }\end{array}$ & 3.76 & 0.9 & 0.0 & 11.1 & 23.8 & 42.9 & 22.2 \\
\hline $\begin{array}{l}\text { The evaluation procedures of the } \\
\text { teaching-learning process must be } \\
\text { known to the students. }\end{array}$ & 4.59 & 0.8 & .5 & 3.2 & 7.4 & 14.8 & 74.1 \\
\hline $\begin{array}{l}\text { The evaluation in some cases is used } \\
\text { as a control tool. }\end{array}$ & 4.23 & 0.9 & 1.6 & 2.1 & 14.8 & 34.9 & 46.6 \\
\hline $\begin{array}{l}\text { In the teaching-learning processes, } \\
\text { the most important thing is to pass. }\end{array}$ & 2.02 & 1.2 & 47.1 & 22.2 & 17.5 & 8.5 & 4.8 \\
\hline $\begin{array}{l}\text { In education, standardised } \\
\text { assessments account for the real } \\
\text { learning that students have. }\end{array}$ & 2.16 & 1.2 & 41.3 & 21.2 & 21.7 & 12.2 & 3.7 \\
\hline $\begin{array}{l}\text { Assessment of learning can improve } \\
\text { pedagogical practices. }\end{array}$ & $\underline{4.1}$ & 1.0 & 2.6 & 3.7 & 16.9 & 34.9 & 41.8 \\
\hline
\end{tabular}

$\mathrm{M}=$ Mean, $\mathrm{SD}=$ Standard Deviation, $\mathrm{TD}=$ Totally Disagree, PD = Partially Disagree,

NA / ND = Neither Agree / Neither Disagree, PA = Partially Agree, $\mathrm{TA}=$ Totally Agree

The results show that, in the second dimension, the participants can position themselves (NA / ND $=17.6 \%$, versus $82.4 \%$ ) against the questions consulted. It is possible to assess low scores and negative results when they are consulted about the function of the standardised evaluation to account for the real learning of students $(\mathrm{M}=2.16, \mathrm{SD}=1.2)$ and in the item that relates the evaluation to pass during the teaching and learning process $(\mathrm{M}=2.02, \mathrm{SD}=1.2)$.

Positive and moderate ratings are found when the participants were consulted about the importance of grading in the teaching and learning process. This is the case as in the following items: it is important to grade students to see whether they should be promoted or failed $(\mathrm{M}=3.12, \mathrm{SD}=1.2)$ and learning assessment is essential 
to grade students $(\mathrm{M}=3.46, \mathrm{SD}=1.1)$, the responses are predominantly partially in agreement in these two cases (37.6\% and $40.2 \%$, respectively).

On the evaluation as a tool for the teacher, it is possible to appreciate values above the mean in items such as learning assessment allows the teacher to compare their students based on the results they obtain $(\mathrm{M}=3.59, \mathrm{SD}=1.1)$ and the evaluation is an instrument that allows knowing the students $(\mathrm{M}=3.48, \mathrm{SD}=1.4)$. Similarly, a high degree of agreement is obtained $(\mathrm{PA}=42.9 \%$ and $45.5 \%$ and $\mathrm{TA}=22.8 \%$ and $22.2 \%$ ) respectively when referring to whether the learning assessment allows students to self-regulate their educational processes $(\mathrm{M}=3.76, \mathrm{SD}=0.9)$ and whether the evaluation is a mechanism that regulates teaching-learning process $(\mathrm{M}=3.78, \mathrm{SD}=$ $1.0)$.

Positive and strong ratings were found in six questions consulted. Three of them are the student assessment is a useful practice for the teacher $(\mathrm{M}=3.96, \mathrm{SD}=0.9)$, the evaluation in education is an important tool to measure the achievement of student learning $(\mathrm{M}=3.96, \mathrm{SD}=1.7)$ and learning assessment can improve pedagogical practices $(\mathrm{M}=4.1, \mathrm{SD}=1.0)$. The remaining three are those with the highest degree of agreement and they are:

- the evaluation in some cases is used as a control tool (PA $=34.9 \%, \mathrm{TA}=46.6 \%)$,

- once an assessment instrument has been applied, it is necessary to analyze the results with the students $(\mathrm{PA}=25.4 \%, \mathrm{TA}=67.2 \%)$, and

- the evaluation procedures that are carried out in a teaching-learning process must be known by the students $(\mathrm{PA}=14.8 \%, \mathrm{TA}=74.1 \%)$.

Table 6 shows the mean values and the standard deviation of the dimension perceptions about the evaluation during the training processes for the total sample. Moreover, the percentages of responses that support the subsequent descriptive analysis are indicated.

Table 6: Perception of evaluation during the training process and professional practices

\begin{tabular}{|l|c|c|c|c|c|c|c|}
\hline Descriptors & $\mathbf{M}$ & $\mathrm{SD}$ & $\begin{array}{c}\text { TD } \\
\%\end{array}$ & $\begin{array}{c}\text { PD } \\
\%\end{array}$ & $\begin{array}{c}\text { NA/ND } \\
\%\end{array}$ & $\begin{array}{c}\text { PA } \\
\%\end{array}$ & $\begin{array}{c}\text { TA } \\
\%\end{array}$ \\
\hline $\begin{array}{l}\text { Teachers working in schools are well } \\
\text { trained to develop learning } \\
\text { assessment. }\end{array}$ & $\underline{2.82}$ & 1.1 & 11.1 & 30.2 & 30.2 & 22.8 & 5.8 \\
\hline $\begin{array}{l}\text { Initial teacher training provides a } \\
\text { solid basis for evaluating student } \\
\text { learning. }\end{array}$ & $\underline{3.20}$ & 1.2 & 10.6 & 18.5 & 23.8 & 34.4 & 12.7 \\
\hline $\begin{array}{l}\text { University teachers have developed } \\
\text { an evaluation that allows them to } \\
\text { improve the learning processes. }\end{array}$ & $\underline{3.03}$ & 1.0 & 8.5 & 21.2 & 36.0 & 28.0 & 6.3 \\
\hline $\begin{array}{l}\text { Your university professors have made } \\
\text { evaluation an instance of learning. }\end{array}$ & $\underline{3.21}$ & 1.1 & 10.1 & 16.4 & 25.9 & 38.1 & 9.5 \\
\hline $\begin{array}{l}\text { The evaluations that have been } \\
\text { applied in your pedagogy agreed with } \\
\text { the objectives of the subject or } \\
\text { branch. }\end{array}$ & $\underline{3.45}$ & 1.1 & 6.3 & 12.2 & 26.5 & 40.2 & 14.8 \\
\hline $\begin{array}{l}\text { Your evaluation processes at the } \\
\text { university were always transparent. }\end{array}$ & $\underline{2.98}$ & 1.2 & 12.2 & 25.9 & 23.8 & 27.5 & 10.6 \\
\hline
\end{tabular}




\begin{tabular}{|l|l|l|l|l|l|l|l|}
\hline $\begin{array}{l}\text { In your university study process, after } \\
\text { being evaluated, you were given some } \\
\text { kind of feedback. }\end{array}$ & $\underline{3.03}$ & 1.1 & 11.1 & 22.8 & 24.3 & 36.0 & 5.8 \\
\hline
\end{tabular}

$\mathrm{M}=$ Mean, $\mathrm{SD}=$ Standard Deviation, $\mathrm{TD}=$ Totally Disagree, $\mathrm{PD}=$ Partially Disagree, NA / ND = Neither Agree / Neither Disagree, PA = Partially Agree, $\mathrm{TA}=$ Totally Agree

The results obtained in this dimension which relates to knowing/determining the perceptions of how the experience has been in their professional practices and how they have been evaluated in their initial teacher-training programme show a mean of 3.1 with a standard deviation of 1.1. Under such an average mean, it is possible to understand the responses such as the teachers who work in schools are well trained to develop the learning assessment $(\mathrm{M}=2.82, \mathrm{SD}=1.1)$ and the evaluation processes to which they have been subjected at the university were always transparent $(\mathrm{M}=2.98, \mathrm{SD}=1.2)$.

Around the sample mean, the items university teachers have developed an evaluation that allows them to improve their learning processes $(\mathrm{M}=3.03, \mathrm{SD}=1.0)$, and in their university study process, after being evaluated, they were given some type of feedback $(\mathrm{M}=3.03, \mathrm{SD}=1.1)$ show a tendency to be evaluated slightly positively, TD and $\mathrm{PD}=29.7 \%$ versus $34.3 \%$ for PA and TA in the case of the first referred item, and $\mathrm{TD}$ and $\mathrm{PD}=33.9 \%$ versus $41.8 \%$ in the case of the second item referring to the subsequent feedback received after the evaluation.

On the mean of the scale, a level of responses not greater than $50 \%$ of degrees of the agreement for the following items was obtained with a predominance of responses that tend to be partially in agreement:

- initial teacher training provides a solid basis for evaluating student learning ( $\mathrm{M}=$ $3.2, \mathrm{SD}=1.2), \mathrm{PA}=34.4 \%$,

- their university professors have made the evaluation an instance for learning $(\mathrm{M}=$ $3.21, \mathrm{SD}=1.1) \mathrm{PA}=38.1 \%$, and

- the evaluations that have been applied during the training stage were in agreement with the objectives of the subjects or branches $(\mathrm{M}=3.45, \mathrm{SD}=1.1) \mathrm{PA}=40.25 \%$.

To analyse possible statistically significant differences in the students' perceptions according to the different training courses (pedagogy career), the Kruskal-Wallis $\mathrm{H}$ test was carried out. The results are shown in Table 7.

Table 7: Kruskal-Wallis $H$ test for group differences

\begin{tabular}{|l|l|l|l|l|}
\hline \multicolumn{1}{|c|}{ Descriptors } & $\begin{array}{l}\text { Chi- } \\
\text { squared }\end{array}$ & Gl & $\mathbf{p}$ & $\begin{array}{l}\text { Pedagogy } \\
\text { careers }\end{array}$ \\
\hline $\begin{array}{l}\text { Learning evaluation is essential to grade } \\
\text { students. }\end{array}$ & 12.416 & 4 & 0.015 & P.I. < O.P. \\
\hline $\begin{array}{l}\text { It is important to grade students to see } \\
\text { whether they should be promoted or failed. }\end{array}$ & 20.182 & 4 & 0.00 & P.I. < O.P \\
\hline Evaluating is the same as grading. & 9.524 & 4 & 0.049 & P.I. < O.P \\
\hline $\begin{array}{l}\text { Teachers working in schools are well trained } \\
\text { to develop an assessment of learning. }\end{array}$ & 19.559 & 4 & 0.001 & P.I. < O.P \\
\hline $\begin{array}{l}\text { Learning evaluation allows students to self- } \\
\text { regulate their educational processes. }\end{array}$ & 12.490 & 4 & 0.014 & P.I. < O.P. \\
\hline The psychometric evaluation has the same & 10.290 & 4 & 0.036 & P.E D. < \\
\hline
\end{tabular}




\begin{tabular}{|l|l|l|l|l|}
\hline $\begin{array}{l}\text { function as the formative pedagogical } \\
\text { evaluation. }\end{array}$ & & & & O.P. \\
\hline $\begin{array}{l}\text { The evaluation procedures that are carried out } \\
\text { in a teaching-learning process must be known } \\
\text { to the students. }\end{array}$ & 22.208 & 4 & 0.000 & P.R. < O.P. \\
\hline $\begin{array}{l}\text { The evaluation in some cases is used as a } \\
\text { control tool. }\end{array}$ & 9.980 & 4 & 0.041 & P.R. < O.P. \\
\hline $\begin{array}{l}\text { In education, standardised evaluations } \\
\text { account for the real learning that students } \\
\text { have. }\end{array}$ & 34.100 & 4 & 0.000 & $\begin{array}{l}\text { P.E D. }< \\
\text { O.P. }\end{array}$ \\
\hline $\begin{array}{l}\text { The evaluations applied to you in your initial } \\
\text { teacher training always agreed with the } \\
\text { objectives of the subject or branch. }\end{array}$ & 26.619 & 4 & 0.000 & $\begin{array}{l}\text { P.E D. }< \\
\text { O.P. }\end{array}$ \\
\hline $\begin{array}{l}\text { The evaluations applied to you in your initial } \\
\text { teacher training always agreed with the } \\
\text { objectives of the subject or branch. }\end{array}$ & 15.349 & 4 & 0.004 & $\begin{array}{l}\text { P.E D. }< \\
\text { O.P. }\end{array}$ \\
\hline $\begin{array}{l}\text { In your university study process, after being } \\
\text { evaluated, you were given some kind of } \\
\text { feedback. }\end{array}$ & 22.432 & 4 & 0.000 & $\begin{array}{l}\text { P.E D. }< \\
\text { O.P. }\end{array}$ \\
\hline Evaluation is focusing on student grades. & 15.619 & 4 & 0.004 & P.I. < O.P. \\
\hline
\end{tabular}

P.I. $=$ Pedagogy in English, P.R. $=$ Pedagogy in Religion and Philosophy, P.E.D = Pedagogy in Differential Education, O.P. = Other pedagogies

The results of the Kruskal-Wallis $\mathrm{H}$ test show the presence of 13 items with a statistically significant difference between the groups. According to the dimension of the instrument, three of them are presented in the first dimension about the perception of what is evaluation, and six in the second dimension about the function and purposes of evaluation. Finally, four items in the third dimension of evaluation during the training process and professional practices show statistically significant differences.

Concerning the perceptions of the students who show statistically significant differences are the students of Pedagogy in English who report six differentiating items with their peers. These correspond to the following items:

- learning evaluation is essential to grade students,

- it is important to grade to promote or fail,

- evaluating is the same as grading,

- teachers in schools are trained to evaluate,

- evaluation for self-regulation, and

- evaluation is focusing on student grades.

The students of Pedagogy in Religion and Philosophy show differences with the other groups in two questions related to the transparency of the evaluation process and post-evaluation feedback. The students of Pedagogy in Differential Education present significant differences in five items of the instrument, as compared to the other pedagogies. These items are the following:

- the psychometric evaluation and the formative evaluation fulfill the same function,

- the standardized evaluation accounts for real learning,

- the evaluations applied in its training were consistent with the objectives,

- the transparency in the evaluation processes to which it was subjected, and

- whether he was given feedback after being evaluated. 


\section{Discussions and Conclusion}

The evolution that the concept of evaluation has undergone throughout history cannot be developed outside of an epistemological interpretation. Alcaraz (2015) and Carbajosa (2011) indicate that its development is based on the researchers' different paradigmatic perspectives. The ways of conceptualising the evaluation of learning are culturally anchored and follow a paradigmatic look to conceive reality in certain moments and contexts. Therefore, we can identify two viewpoints, one from a positivist and the other from an interpretive perspective. In the first category, Tyler (1967), Thorndike and Hagen (1970), Mager (1973) and Chadwick (1976) developed an evaluation oriented to measurement, statistics and systemic study. However, in the second one, researchers such as Scriven (1981), Stake (1999), House (1994), Eisner (1985), Stenhouse (1984), MacDonald (1974) and Elliott (1993) conceived evaluation as an understanding exercise that involves the entire teaching-learning process (Carbajosa, 2011).

Therefore, it is relevant to consider that the evaluative practices implemented during the initial teacher training process will positively or negatively regulate the professional performance of the future teachers because the transposition of the evaluation is related to the evaluative competencies acquired during their training process. Evaluations determine and condition the contents, strategies, learning and efforts in educational processes directly with learners (Barbera, 2003; Biggs, 2005; Bonson \& Benito, 2005; Cano, 2008; Dochy, Segers \& Dierick, 2002; Gibbs, 2003; Santos Guerra 1998, 2003; Tejada \& Ruiz, 2016; Zabalza, 2003). Pedagogy students perceive the evaluation of learning as a curricular device that enables improving the teaching and learning processes in students. This is because the participants of this study had an up-to-date perception of the evaluation of learning, its concept and function in the educational processes. This updated perspective considers the evaluation of learning as a means that facilitates the construction of knowledge within the classroom which must be fully integrated into the training processes to achieve a good regulation of teaching and learning. Some researchers state that evaluation with proper implementation enables improving the teaching practices of future teachers (Cabra-Torres, 2011; Gil-Flores, 2012; Santos Guerra, 2003; Sánchez González, 2010; Stobar, 2010).

The results also indicate that the majority of students have a positive assessment of the evaluation experiences developed in their training process. It is also possible to understand that students have incorporated theoretical knowledge related to what is learning assessment. It is necessary that the knowledge acquired by the respondents be reflected in the training activities that they receive from their teachers so that there is a decidedly favourable attitude to the development of a more conscious, reflective, and formative assessment of learning. There is a perception among the learners that the focus of the assessment is mainly on the instrument rather than on the relevance of the whole evaluative process.

The students also perceive that in some cases, evaluation is used as a control tool by their teachers. It is necessary to analyse the perception of students in this area 
since they are contrary to what the specialised literature raises. The students must necessarily experience formative instances in their learning process and the way in which they are evaluated is precisely one of them (Sanmartí, 2007).

Results show that in the initial teacher training processes, authentic evaluation activities must be implemented and adjusted to educational purposes so that the future teachers are involved in the evaluation process and participate in real improvement activities. Statistically significant differences were found in the perceptions of the respondents of the different career courses about the function of the evaluation, specifically, those that refer to the grading, standardisation, control, coherence, transparency, and self-regulation, with transparency being the item that generates differences in all groups. This would indicate that the evaluation to which the students have been subjected lacks elements that benefit this area since the characteristics present and collected through the instrument require its deepening in subsequent studies since the pedagogical device tends to be homogeneous in a heterogeneous educational context.

The results obtained allow us to analyse how pedagogy students perceive and develop evaluation in their formative work and how teacher trainers in the evaluation area could reflect on students' perceptions of professional competencies in the field of evaluation to advance and improve the teaching practices of future teachers. It is suggested future teachers be trained through reflective instances and grounded practices of evaluation, oriented towards the particular characteristics of each pedagogical discipline, the particular environment of the school, and the curricular demands. Through these changes, progress can be made to improve the learning processes that students experience daily in their educational communities.

\section{Acknowledgements}

This work was carried out under the Doctoral Programme in Education in Consortium at the Universidad Católica del Maule, Chile, and the DIUBB Project 195623 4/IenDU-FID of the Universidad del Bio-Bio, Chile.

\section{References}

Alcaraz, N. (2015). Aproximación histórica a la evaluación educativa: De la generación de la medición a la generación ecléctica [Historical approach to educational evaluation: From the measurement generation to the eclectic generation]. Revista Iberoamericana de Evaluación Educativa, 8(1), 11-25.

Ashford-Rowe, K., Herrington, J., \& Brown, C. (2014). Establishing the critical elements that determine authentic assessment. Assessment $\mathcal{E}$ Evaluation in Higher Education, 39(2), 205-222. https://doi.org/10.1080/02602938.2013.819566

Barbera, E. (2003). Estado y tendencias de la evaluación en Educación Superior. [Status and trends of evaluation in Higher Education]. Revista de la Red Estatal de Docencia Universitaria, 3(2), 47- 60.

Biggs, J. (2005). Calidad del aprendizaje universitario. [Quality of university learning]. Madrid: Narcea.

Black, P., \& Williams, D. (1998). Assessment and classroom learning. Assessment in Education, 4(1), 7-71.

Bloom, J. (1969). Taxonomía de los objetivos de la educación. [Taxonomy of educational objectives]. Buenos Aires: Talleres Gráficos Litodar. 
Bonson, M., \& Benito, A. (2005). Evaluación y aprendizaje. In A. Benito y A. Cruz (Eds.), Nuevas claves para la docencia universitaria en el Espacio Europeo de Educación Superior [New keys to university teaching in the European Higher Education Area] (pp. 87-100). Madrid: Narcea

Bound, D., \& Falchikov, N. (2007). Rethinking assessment in higher education learning for the long term. London: Routledge.

Cabra-Torres, F. (2011). Reseña del libro Tiempos de pruebas: Los usos y abusos de la evaluación de Gordon Stobart. [Review of the book Testing Times: The Uses and Abuses of Evaluation by Gordon Stobart] Magis Revista Internacional de Investigación en Educación, 4(7), 211-213.

Cano, M. (2008). La evaluación por competencias en la educación superior [Competencybased assessment in higher education]. Profesorado. Revista de Currículum y Formación de Profesorado, 12(3),1-16.

Carbajosa, D. (2011). Debate desde paradigmas en la evaluación educativa [Debate from paradigms in educational evaluation]. Perfiles educativos, 33(132), 183-192.

Cardona, M. C. (2002). Introducción a los métodos de investigación en educación [Introduction to research methods in education]. Madrid: EOS.

Carless, D., Joughin, G., \& Mok, M. (2006). Learning-oriented assessment: Principles and practice. Assessment \& Evaluation in Higher Education, 31(4), 395-398.

Castillo, S., \& Cabrerizo, J. (2010). Evaluación educativa de aprendizajes y competencias [Educational assessment of learning and competencies]. Madrid: Pearson Educación, S.A.

Centro de Perfeccionamiento, Experimentación e Investigaciones Pedagógicas - CPEIP (2018). Resultados nacionales. Evaluación nacional diagnóstica de la formación inicial docente [National Results. National diagnostic test of initial teacher training]. Chile: Ministerio de Educación.

Chadwick, C. (1976). Tecnología educacional para el docente [Educational technology for teachers]. Buenos Aires: Paidós.

Colás, B. (1994). Investigación educativa [Educational research]. Sevilla: Alfar.

Cronbach, L. (1963). Course improvement through evaluation. New York: Teachers College Record.

Del Pozo, J. (2013). Competencias profesionales. Herramientas de evaluación: El portafolios, la rúbrica y las pruebas situacionales [Professional competencies. Assessment tools: The portfolio, rubric and situational tests]. Madrid: Narcea.

Dochy, F., Segers, M., \& Dierick, S. (2002). Nuevas vías de aprendizaje y enseñanza y sus consecuencias: Una era de evaluación [New avenues of learning and teaching and their consequences: An era of assessment]. Red-U, 2(2), 13- 30.

Escudero, T. (2003). Desde los test hasta la investigación evaluativa actual. Un siglo, el $\mathrm{XX}$, de intenso desarrollo de la evaluación en educación [From tests to current evaluative research. A century, the 20th, of intense development of evaluation in education.]. Relieve, 9(1), 11- 43.

Fernández, A. (2010). La evaluación orientada al aprendizaje en un modelo de formación por competencias en la educación universitaria [Learning-oriented assessment in a competency-based training model in university education]. Revista de Docencia Universitaria, 8(1), 11-34.

Fernández, B. R. (1981). Perspectivas históricas de la evaluación conductual [Historical perspectives on behavioral assessment]. Madrid: Ediciones Pirámide.

Gagné, R. (1971). Las condiciones del aprendizaje [Learning conditions]. Madrid: Aguilar.

Gibbs, G. (2003). Uso estratégico de la evaluación en el aprendizaje [Strategic use of evaluation in learning]. In A. Brown y A. Glasner (Eds.), Evaluar en la universidad. Problemas y nuevos enfoques (pp. 61-75). Madrid: Narcea 
Gil-Flores, J. (2012). La evaluación del aprendizaje en la universidad según la experiencia de los estudiantes [The assessment of learning in the university as experienced by students]. ESE. Estudios Sobre Educación, 22, 133-153.

Guba, G., \& Lincoln, Y. (1982). Effective evaluation. USA: Jossey-Bass.

Hall, K., \& Burke, W. (2003). Making formative assessment work: Effective practice in the primary classroom. United Kingdom: Open University Press.

Hernández, R., Fernández, C., \& Baptista, M. (2010). Metodología de la investigación (5 edición) [ Research Methodology, 5th edition]. México: McGraw-Hill Interamericana.

Jaimes, G., \& Callejas, M. (2009). La autonomía, los procesos de pensamiento y las TIC: competencias del siglo XXI. Temática contemporánea de aplicación en escuelas, colegios $y$ universidades [Autonomy, thought processes and ICT: 21st century competencies. Contemporary topics of application in schools, colleges and universities]. Bogotá: Limusa Noriega.

Kaftan, J., Buck, G., \& Haack, A. (2006). Using formative assessments to individualize instruction and promote learning. Middle School Journal, Westerville, 37(4), 44-49.

Littlewood, K. (1973). High fidelity simulation as a research tool. Best Practice \& Research Clinical Anesthesiology, 25, 473-487. https://doi.org/10.1016/j.bpa.2011.08.001.

Mager, R. (1973). Análisis de metas [Goal analysis]. México: Trillas.

McGaghie, W. C, Issenberg, S. B., Petrusa, E. R., \& Scalese, R. J. (2010). A critical review of simulation-based medical education research: 2003-2009. Medical Education, 44, 50-63. https://doi.org/10.1111/j.1365-2923.2009.03547.x

Ministerio de Educación. (2019a). Centro de Perfeccionamiento, Experimentación e Investigaciones Pedagógicas. Resultados Nacionales. Resultados Nacionales Evaluación Docente 2018 [National Results of Teacher Evaluation 2018.

Ministerio de Educación. (2019b). Centro de Perfeccionamiento, Experimentación e Investigaciones Pedagógicas. Resultados Nacionales. Evaluación Nacional Diagnostica de la Formación Inicial Docente 2018 [National Diagnostic Test of Initial Teacher Training 2018.].

Perrenoud, P. (2004). Diez nuevas competencias para enseñar [Ten new competencies for teaching]. Barcelona: Graó.

Ros, M., \& Conesa, C. (2013). Adquisición de competencias a través de la simulación y juego de rol en el área contable [Acquisition of competencies through simulation and role-playing in the accounting área]. Estudios sobre el Mensaje Periodístico, 19, special number, 419-428. https://doi.org/10.5209/rev_ESMP.2013.v19.42049.

Ríos, D., \& Herrera, D. (2017). Los desafíos de la evaluación por competencias en el ámbito educativo [The challenges of competency-based assessment in education]. Educação e Pesquisa, 43(4), 1073-1086.

Ruay Garces, R. (2019). Nuevos dispositivos de evaluación de aprendizajes en un enfoque curricular por competencias [New learning assessment devices in a competency-based curricular approach]. In Consejo de Decanos de Facultades de Educación del Consejo de Rectores de las Universidades Chilenas, Educación, escuela y profesorado: Aportes desde el Consejo de Decanos de Facultades de Educación del Consejo de Rectores de las Universidades Chilenas (pp. 317 - 336). Concepción: Editorial Universidad de Concepción.

Sacristán, J., Pérez, A., Martínez, J., Torres, J., Angulo, F., \& Álvarez, J. (2008). Educar por competencias, ¿qué hay de nuevo? [Educating by competencies, what's new?]. España: Ediciones Morata.

Salazar-Gómez, E., \& Tobón, S. (2018). Análisis documental del proceso de formación docente con la sociedad del conocimiento [Documentary analysis of the teacher training process with the knowledge society]. Espacios, 39(53), 17-29. 
Sánchez González, M. (2010). Técnicas docentes y sistemas de Evaluación en Educación Superior [Teaching Techniques and Evaluation Systems in Higher Education]. España: Narcea.

Sanmartí, N. (2007). 10 ideas clave: Evaluar para aprender [10 key ideas: Evaluate to learn]. Madrid: Graó.

Santos Guerra, M. (1998). Evaluar es comprender [To evaluate is to understand]. Buenos Aires: Editorial Magisterio del Río de la Plata.

Santos Guerra, M. (2003). Una flecha en la diana. Evaluación como aprendizaje [An arrow in the bull's eye. Evaluation as learning]. Madrid: Ediciones Narcea, S. A.

Scriven, M. (1967). The methodology of evaluation. In R. W. Tyler, R. M. Gagné, \& M. Scriven (Eds.), Perspectives of curriculum evaluation. Chicago, IL: Rand McNally.

Scriven, M. (2007). The logic of evaluation. In: H. V. Hansen et al. Dissensus and the search for common ground (pp. 1-16), Windsor, ON: OSSA.

Sistema de Evaluación del Desempeño Profesional Docente. (2019). Informe de resultados Evaluación Docente 2019 [2019 Teacher Evaluation Results Report]. Chile: Ministerio de Educación.

Stobart, G. (2010). Tiempos de pruebas: Los usos y abusos de la evaluación [Testing times: The uses and abuses of evaluation]. España: Ediciones Morata.

Tejada, F., \& Ruiz, C. (2016). Evaluación de competencias profesionales en Educación Superior: Retos e implicaciones [Assessment of professional competencies in Higher Education: Challenges and implications]. Educación XX1, 19(1), 17-38. https://doi.org/10.5944/educXX1.12175.

Tejedor, F. (2000). El diseño y los diseños en la evaluación de programas [Design and designs in evaluative programs]. Revista de Investigación Educativa, 18(2), 319-339.

Thorndike, R. \& Hagen, E. (1970). Test y técnicas de medición en psicología y educación. México, Trillas.

Tobón, S. (2004). Formación basada en competencias: Pensamiento complejo, diseño curricular y didáctica [Competency-based education: Complex thinking, curriculum design and didactics]. Bogotá: ECOE.

Tyler, R. W. (1950). Basic principles of curriculum and instruction. Chicago: University of Chicago Press.

Tyler, R. W. (1967). Changing concepts of educational evaluation. In R. E. Stack (Comp.), Perspectives of curriculum evaluation. AERA Monograph Series Curriculum Evaluation, 1. Chicago, IL: Rand McNally.

Zabalza, M. (2003). Diseño curricular en la universidad. Competencias del docente universitario [Curriculum design at the university. Competencies of university teachers]. Madrid: Narcea. 